\title{
Evaluating Knowledge of Autonomic Dysreflexia Among Physicians in a Tertiary Hospital
}

\section{Bir Üçüncü Basamak Hastanesindeki Hekimler Arasında Otonomik Disrefleksinin Bilinirliğinin Değerlendirilmesi}

\author{
(1) Fatih Tarhan, (1) Alper Coşkun, (1) Bilal Eryıldırım, (1) Kemal Sarıca \\ istanbul Kartal Dr. Lütfi Kırdar Training and Research Hospital, Clinic of Urology, İstanbul, Turkiye
}

\section{What's known on the subject? and What does the study add?}

Autonomic dysreflexia is a potentially life-threatening emergency status in patients with spinal cord injury involving the level of T6-T8 or above. Therefore, prevention and early diagnosis of autonomic dysreflexia is of vital significance. However, previous studies revealed that health care workers, patients and their families, and caregivers had inadequate knowledge about autonomic dysreflexia. Studies focusing on the physician' knowledge of autonomic dysreflexia are very limited. This is the first study investigating the knowledge of autonomic dysreflexia among physicians of the relevant departments in the literature.

\begin{abstract}
Objective: To evaluate the level of knowledge of autonomic dysreflexia among physicians practicing in different disciplines namely anesthesia and reanimation, emergency, neurology, neurosurgery, urology, and physical medicine and rehabilitation departments.

Materials and Methods: The study was conducted using a questionnaire consisting of seven questions, which was completed in a prospective manner by 95 physicians (residents and consultants) in our tertiary care hospital.

Results: None of the questions asked in the questionnaire could be replied by 38 (40\%) of 95 physicians in the hospital. Only one physician did reply all the questions completely. The mean value of the mark given was $2.00 \pm 2.04$ for consultants and $1.10 \pm 1.37$ for residents ( $p=0.039$ ). 0 ur data showed that while only $27 \%$ of the physicians have received training on autonomic dysreflexia; $18 \%$ of physicians had a previous experience with patients having autonomic dysreflexia.

Conclusion: Taking the potential serious complications of autonomic dysreflexia into account, necessary information on this emergency status should be given to physicians. We believe that to reach a more precise conclusion about awareness of physicians on autonomic dysreflexia, multicenter studies with larger number of participants are certainly necessary.
\end{abstract}

Keywords: Autonomic dysreflexia, Spinal cord injury, Physician, Knowledge

Öz

Amaç: Farkıı branşlarda (anestezi ve reanimasyon, acil tıp, nöroloji, beyin cerrahisi, üroloji, fizik tedavi) çalışan hekimlerin otonomik disrefleksi hakkındaki bilgi düzeylerini değerlendirmek amaçlandı.

Gereç ve Yöntem: Yedi sorudan oluşan ölçme ve değerlendirme anketi hastanemizde çalışan uzman ve asistanlardan oluşan 95 hekime uygulandı.

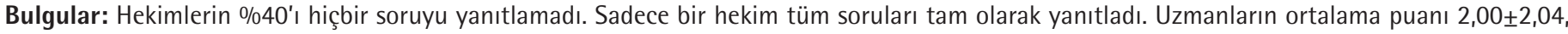

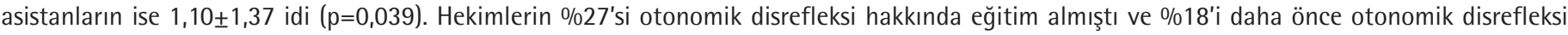
atağı geçiren hastayı görmüştü.

Sonuç: Otonomik disrefleksinin potansiyel ciddi komplikasyonları dikkate alındığında hekimlere bu konuda daha yoğun bir eğitim verilmelidir. Kesin sonuca varmak için çok merkezli, daha fazla katılımcıyı içeren çalışmalara ihtiyaç vardır.

Anahtar Kelimeler: Otonomik disrefleksi, Spinal kord yaralanması, Hekim, Bilgi

Correspondence: Fatih Tarhan MD, İstanbul Kartal Dr. Lütfi Kırdar Training and Research Hospital, Clinic of Urology, İstanbul, Turkiye Phone: +90 5327223435 E-mail: tarhanf@yahoo.com ORCID-ID: orcid.org/0000-0001-8168-0420

Received: 23.11.2017 Accepted: 22.01.2018

Cite this article as: Tarhan F, Coşkun A, Eryıldırım B, Sarıca K. Evaluating Knowledge of Autonomic Dysreflexia Among Physicians in a Tertiary Hospital. J Urol Surg 2018;5(2):88-92

๑Copyright 2018 by the Association of Urological Surgery / Journal of Urological Surgery published by Galenos Publishing House. 


\section{Introduction}

Autonomic dysreflexia is a potentially life-threatening emergency status in patients with spinal cord injury involving the level of T6-T8 or above. An uncontrolled reflex sympathetic discharge occurs as a result of loss of the autonomic response that coordinates heart and vascular tone to sensorial stimuli $(1,2,3)$. Distal cord viability is a prerequisite (1).

Autonomic dysreflexia may occur in patients with complete or incomplete spinal cord injury, tumors and autoimmune-induced myelodysplasia $(3,4,5)$. The frequency of autonomic dysreflexia has been reported to be $20 \%$ to $70 \%$ in cases with chronic spinal cord injury at the level of T6 or above (6). Usually, the symptoms start after the spinal shock period but it may take several years after injury to observe this pathology $(1,2,3)$.

Autonomic dysreflexia is triggered by a massive discharge of the sympathetic preganglionic neurons. Stimuli from the urinary bladder, intestine, striated muscle, and skin cause this sympathetic discharge (3). Genitourinary organ-originated stimuli are the most common causes (81\%-87\%) (7). The second source of stimuli is the gastrointestinal tract $(20 \%)(6,7,8)$.

Early diagnosis of autonomic dysreflexia is of paramount importance and physicians should remember the pathology in the presence of minimal symptoms or sometimes even in the absence of characteristic symptoms. Characteristic symptoms of autonomic dysreflexia are paroxysmal hypertension, pounding headache, bradycardia and sweating and flushing above the level of the lesion, and piloerection below the level of the lesion $(1,2,3)$. The classical symptoms triad including severe headache and sweating and vasodilatation of the skin above the level of the lesion may be detected in around 85\% of patients (3). Symptoms may be atypical or minimal (silent autonomic dysreflexia) $(2,3,6)$. Migraine, pheochromocytoma, cluster headache, and posterior cranial fossa tumors should be considered in the differential diagnosis (3).

In this study, we aimed to evaluate the level of knowledge of autonomic dysreflexia among physicians working in the relevant departments (anesthesia and reanimation, emergency medicine, neurology, neurosurgery, urology and physical medicine and rehabilitation departments) in our hospital.

\section{Materials and Methods}

This study was performed in a training and research hospital. A measurement and evaluation questionnaire previously used in a study of the knowledge of autonomic dysreflexia (9) was utilized. The questionnaire consists of seven questions about description, clinics, treatment, and complications of autonomic dysreflexia. Additionally, all participant physicians were asked if they had evaluated any patient with autonomic dysreflexia attack and undergone training about autonomic dysreflexia.

All procedures followed were in accordance with the ethical standards of the responsible committee on human experimentation and with the Helsinki Declaration of 1975, as revised in 2000. The study did not have approval of the ethics committee but, informed consent was obtained from all participants for being included in the study.

A hundred five physicians worked in the different clinics of the hospital where the study was conducted. Ten of them did not participate in the study. The questionnaire was administered to 49 residents and 46 consultants, totally 95 physicians. The questionnaire was distributed to the physicians working in the anesthesia and reanimation (residents $n=19$, consultants $n=16$, total: 35), emergency medicine (residents $n=14$, consultants $n=8$, total: 22 ), neurology (residents $n=4$, consultants $n=3$, total: 7), neurosurgery (residents $n=4$, consultants $n=7$, total: 11 ), urology (residents $n=8$, consultants $n=8$, total: 16 ), and physical medicine and rehabilitation (consultants $n=4$ ) departments at our hospital and the participants were asked to fill out the questionnaire in fifteen minutes during consecutive two days. Subsequently, a review of autonomic dysreflexia was delivered to all participants and they were informed about autonomic dysreflexia (10). The responses were evaluated and compared with the standardized answers. One point was scored for each correct response for a maximum of 7 points (Table 1).

\section{Statistical Analysis}

Descriptive data were presented as percentage and mean \pm standard deviation. Normality of the data was assessed using the Kolmogorov-Smirnov test. Continuous variables were compared using the Mann-Whitney $\mathrm{U}$ test. Categorical variables were compared by a chi-square test. The Kruskal-Wallis test was used to compare three or more unmatched groups. A p value of less than 0.05 was considered statistically significant. Statistical analyses were performed using the GraphPad Prizm 5.0 software.

\section{Results}

Ninety-five physicians (64\% men and 36\% women) responded to the questionnaire with a response rate of $91 \%$. The mean age of the respondents was $37.9 \pm 9.2$ years.

The training and experience rates in consultant and residents are shown in Table 2. Twenty-six physicians (27\%) had previously received training about autonomic dysreflexia and 17 of them (18\%) reported to evaluate a patient referred with an autonomic dysreflexia attack. While the rate of education among the residents was the lowest in the neurosurgery clinic $(0 \%)$, the highest rates were obtained in the urology $(63 \%)$ and anesthesia clinics (37\%); at the same time, the rate of education 
among consultants was the lowest in the neurologist and neurosurgeons $(0 \%)$, and the highest in the physical medicine and rehabilitation consultants (75\%). The rates of experience on autonomic dysreflexia attacks among residents were the lowest in the neurosurgery clinic (0\%), and the highest in the neurology clinic (50\%). These rates among consultants were the lowest among the neurologists and the brain surgeons (0\%), and the highest in the physical medicine and rehabilitation consultants (75\%).

Thirty-eight physicians (40\%) participating in this study could not answer any question. Only one consultant answered all the questions correctly. There was no statistically significant differences in these parameters between consultants and residents ( $p>0.05$ ) (Table 2$)$.

Table 1. Questions and answers about autonomic dysreflexia (10)

Question 1 What is the autonomic dysreflexia?

Sympathetic outflow, noxious stimuli below lesion, unopposed

Question 2 What are the signs and symptoms of autonomic dysreflexia?

Flushing and sweating above injury, nasal stuffiness, goosebumps and paleness below injury, hypertension, bradycardia, pounding headache, blurred vision and spots invisual fields, arrhythmias, anxiety

Question 3 Who is at risk of autonomic dysreflexia? Spinal cord injury at or above T6

Question 4 What are the common causes of autonomic dysreflexia?

One each for bladder distension, bowel distension, then $1 / 2$ for any others

Question 5 What is the treatment for autonomic dysreflexia?

Recognize signs, sit up, check blood pressure, loosen clothing, treat cause, and check catheter, check bowel, pain relief, and glyceryl trinitrate spray

Question 6 What are the potential complications of autonomic dysreflexia?

Intracranial hemorrhage, convulsions, death

Question 7 What is the normal systolic blood pressure in tetraplegic patients?

90-110 $\mathrm{mmHg}$

Table 2. Training, experience, null and full response rates of physicians

\begin{tabular}{lllll}
\hline & $\begin{array}{l}\text { Consultant } \\
(\mathbf{n = 4 6 )} \\
\mathbf{n}(\%)\end{array}$ & $\begin{array}{l}\text { Resident } \\
(\mathbf{n = 4 9 )}\end{array}$ & $\begin{array}{l}\text { Total } \\
\mathbf{n}(\mathbf{n}=\mathbf{9 5})\end{array}$ & $\begin{array}{l}\text { p value* } \\
\mathbf{n}(\%)\end{array}$ \\
\hline Training & $11(24)$ & $15(31)$ & $26(27)$ & 0.498 \\
Patient experience & $11(24)$ & $6(12)$ & $17(18)$ & 0.183 \\
No response & $14(30)$ & $24(49)$ & $38(40)$ & 0.093 \\
Full response & $1(2)$ & $0(0)$ & $1(1)$ & 0.484 \\
\hline${ }^{*}$ Chi-square test & & & & \\
\hline
\end{tabular}

The rate of correct answer to the $1^{\text {st }}$ question among was lower among the consultants (22\%), and higher to the $3^{\text {rd }}$ question $(50 \%)$. However, the rate of correct answer to the $4^{\text {th }}$ question was lower among the residents (8\%) and higher to the $3^{\text {rd }}$ question (37\%).

Scores of consultant and resident physicians are given in Table 3. There was a statistically significant difference in scores between consultants and residents $(p=0.039)$. Although consultants in the physical medicine and rehabilitation department had the highest score, those in the urology clinic had the lowest score. There was a statistically significant differences in scores between consultants from different sections $(p=0.020)$. The scores of residents were the highest in the anesthesia clinic and the lowest in the urology clinic. There was no statistically significant differences in scores between residents from different sections $(p=0.386)$ (Table 3$)$.

\section{Discussion}

Being first reported as a case report by Hilton in 1860 and then by Bowlby in 1890 (2); autonomic dysreflexia represents a fatal complication of spinal cord injury. The pathology has been defined in several forms namely autonomic hyperreflexia, spinal poikilopiesis, neurogenic paroxysmal hypertension, autonomic dysreflexia, sympathetic hyperreflexia, mass reflex and neurovegetative syndrome $(3,7)$.

The basics of effective treatment principles for this pathology are the recognition of symptoms and signs along with the prevention the precipitating causes. Related with this subject, early identification and elimination of triggering factors followed by an immediate pharmacological treatment are very important to prevent complications including intracranial and retinal bleeding, convulsions, cardiac arrhythmias and death $(3,7)$

Table 3. Scores of consultants and residents from different sections (mean \pm SD)

\begin{tabular}{lll}
\hline Department & $\begin{array}{l}\text { Consultant } \\
(\mathbf{n}=46)\end{array}$ & $\begin{array}{l}\text { Resident } \\
(\mathbf{n}=49)\end{array}$ \\
\hline Anesthesia and reanimation & $1.16 \pm 1.48$ & $1.55 \pm 1.75$ \\
Emergency medicine & $3.14 \pm 2.34$ & $1.21 \pm 1.17$ \\
Neurology & $3.25 \pm 1.77$ & $0.50 \pm 1.00$ \\
Neurosurgery & $1.93 \pm 1.64$ & $0.63 \pm 0.75$ \\
Urology & $1.00 \pm 1.54$ & $0.38 \pm 0.52$ \\
Physical medicine and rehabilitation & $4.88 \pm 2.02$ & - \\
Total & $2.00 \pm 2.04$ & $1.10 \pm 1.37$ \\
p value* & 0.020 & 0.386 \\
\hline $\begin{array}{l}\text { SD: Standard deviation } \\
\text { *Kruskal-Wallis test }\end{array}$ & & \\
\hline
\end{tabular}


This study demonstrates that physician awareness of this condition is inadequate. Additionally, there are differences in knowledge of autonomic dysreflexia between physicians from different departments. This may be due to lack of experience and training in this regard. As a matter of fact, doctors who were trained and experienced, such as physical medicine and rehabilitation consultants, had higher scores.

It is vital that all patients and caregivers of patients with spinal cord injury must be properly educated about autonomic dysreflexia. Clinicians are responsible for educating patients and caregivers of patients with spinal cord injury. Therefore, lack of their knowledge will lead to inadequate awareness of autonomic dysreflexia among patients and their caregivers. The reason for lack of awareness of this issue which may result in extremely serious consequences was lack of appropriate training programs for the related physicians in this regard. Our findings indicate that the knowledge of autonomic dysreflexia should be well instituted with appropriate and adequate educational programs.

It has been reported by several studies that knowledge of autonomic dysreflexia among physicians was very limited. Jackson and Acland (9) found that health care workers (doctors and nurses) practicing in emergency department and spinal unit had limited information about autonomic dysreflexia. While Sullivan et al. (11) emphasized the actual need for training for dentists about autonomic dysreflexia, in another study, McGillivray et al. (12) have shown that patients with spinal cord injury and their families had poor awareness of autonomic dysreflexia. Schottler et al. (13) also found that patients with spinal cord injury and their caregivers had inadequate knowledge of autonomic dysreflexia.

This is the first study investigating the knowledge of autonomic dysreflexia among physicians from the related departments only. In our study, to outline the level the knowledge of autonomic dysreflexia; a questionnaire-based study was performed among physicians practicing in different disciplines that may provide care to patients suffering autonomic dysreflexia. Additionally all physicians participated in the study were asked to reply if they had any training on autonomic dysreflexia and/or they had any experience with a patient presenting with autonomic dysreflexia attack. Data obtained in our study demonstrated that, knowledge of autonomic dysreflexia was inadequate among residents as well as consultants.

Many unintended consequences may arise since spinal cord injuries are not known well enough by physicians of the departments other than the relevant ones. Therefore, the patients should carry a card containing information related to the likelihood of autonomic dysreflexia problem and patients, patient' families and caregivers as well as medical staff are also needed to be informed and educated on this aspect.

\section{Study Limitations}

Our study did not include physicians working in all departments. This issue is the main limitations of this study.

\section{Conclusion}

A well programmed training for physicians dealing with patients suffering from spinal cord injury is necessary to prevent serious complications of autonomic dysreflexia. We believe that to reach a more precise conclusion about awareness of autonomic dysreflexia among physicians, multicenter studies with larger number of participants are certainly necessary.

\section{Ethics}

Ethics Committee Approval: The study did not have approval of the ethics committee.

Informed Consent: A consent form was completed by all participants.

Peer-review: Externally peer-reviewed.

\section{Authorship Contributions}

Surgical and Medical Practices: F.T., A.C., Concept: F.T., Design: F.T., A.C., Data Collection or Processing: A.C., B.E., Analysis or Interpretation: F.T., A.C., Literature Search: F.T., Writing: F.T., A.C., B.E., K.S.

Conflict of Interest: No conflict of interest was declared by the authors.

Financial Disclosure: The authors declared that this study received no financial support.

\section{References}

1. Wein AJ, Dmochowski RR. Neuromuscular dysfunction of the lower urinary tract. In: Wein AJ, Kavoussi LR, Novick AC, Partin AW, Peters CA. CampbellWalsh Urology, 10th ed. Philadelphia, ElsevierEtSaunders, 2012, pp 10991946.

2. Perkash I. Pathophysiology of the autonomic dysreflexia. In: Corcos J, Schick E. Textbook of the Neurogenic Bladder, 2nd ed. London, Informa Healthcare, 2008, pp 207-211.

3. Khastgir J, Drake MJ, Abrams P. Recognition and effective management of autonomic dysreflexia in spinal cord injuries. Expert Opin Pharmacother 2007;8:945-956.

4. Milligan J, Lee J, McMillan C, Klassen H. Autonomic dysreflexia: recognizing a common serious condition in patients with spinal cord injury. Can Fam Physician 2012;58:831-835.

5. Bycroft J, Shergill IS, Chung EA, Arya N, Shah PJ. Autonomic dysreflexia: a medical emergency. Postgrad Med J 2005;81:232-235. 
6. Breault G, Altaweel W, Corcos J. Management of autonomic dysreflexia. In: Corcos J, Schick E. Textbook of the Neurogenic Bladder, 2nd ed. London, Informa Healthcare, 2008, pp 598-602.

7. Shergill IS, Arya M, Hamid R, Khastgir J, Patel HR, Shah PJ. The importance of autonomic dysreflexia to the urologist. BJU Int 2004;93:923-926.

8. Blackmer J. Rehabilitation medicine: 1. Autonomic dysreflexia. CMAJ 2003;169:931-935.

9. Jackson $\mathrm{CR}$, Acland R. Knowledge of autonomic dysreflexia in the emergency department. Emerg Med J 2011;28:866-869.
10. Tarhan F. Otonomik Disrefleksi. Kadın ve İşlevsel Üroloji Dergisi 2014;3:82-89

11. Sullivan AL, Morgan C, Bailey J. Dental professionals' knowledge about treatment of patients with spinal cord injury. Spec Care Dentist 2009;29:117122.

12. McGillivray CF, Hitzig SL, Craven BC, Tonack MI, Krassioukov AV. Evaluating knowledge of autonomic dysreflexia among individuals with spinal cord injury and their families. J Spinal Cord Med 2009;32:54-62.

13. Schottler J, Vogel L, Chafetz R, Mulcahey MJ. Patient and caregiver knowledge of autonomic dysreflexia among youth with spinal cord injury. Spinal Cord 2009;47:681-686. 